\title{
IMPORT DEPENDENCE OF INDUSTRIAL ENTERPRISES IN THE REGION AS AN ECONOMIC SECURITY HAZARD
}

Import is traditionally considered as a source for saturation of a home market with scarce commodities or goods non-manufactured in an importing country. However, the larger is the share of import in the total volume of deliveries, the greater is the hazard for economic security of the region and for the state upon the whole. The analysis has revealed the fact that in the regional industry there is a real situation of absolute import dependence. It means that enterprises have been functioning only based on import deliveries to manufacture some single components for products of production-technical purposes.

Steady dynamics of economic relations between countries leads to generation of the world market as a developed sphere of merchandise exchange based on the international division of labor, where an important place is taken also by imports.

Import is traditionally considered as a source for saturation of home market with scarce commodities or goods non-manufactured in an importing country. Since the middle of the nineties of the last century import resources have still been constituting a considerable share of the wholesale commodity turnover structure in the RF.

While using imported raw products and materials, manufacturing equipment, Russian enterprises fall into hazardous dependence on import deliveries. The larger is the share of import in the total volume of deliveries, the greater is the hazard for economic security of the region and for the state upon the whole. In this way import dependence of regional industrial enterprises is generated.
It is quite obvious that import dependence is determined by different types of import. For instance, according to materials of the Federal laws on special protective antidumping and compensation measures in merchandise imports, imports of similar and directly competitive goods for sale can be mentioned [1]. And for industrial enterprises imports of products of technical and industrial use (PTIU) are of considerable importance, as they are composed of such components as: raw stock, materials, component parts, semi-finished products, manufacturing equipment.

As is well-known, import dependence is divided into commodity and geographical one. This paper is based on the analysis of commodity import dependence of industrial enterprises in the Nizhny Novgorod region carried out by the author with respect to products of technical and industrial use in the following two groups of economic activities: Chemical and Petrochemical Industry ${ }^{1}$ and Mechanical Engineering and Metal-Working Industry ${ }^{2}$ for the period from 2007 to 2009.

The questionnaire surveys of the regional industrial enterprises served as a basis for the mentioned analysis of import dependence.

The analysis of import dependence was performed with the purpose to determine quantitative

\footnotetext{
${ }^{1}$ GCKEA - chemical production; manufacture of rubber and plastics

${ }^{2}$ GCKEA - manufacture of transport vehicles and equipment; production of machinery and equipment; manufacture of electric, electronic and optic equipment; metallurgical production and complete metal ware manufacture.
} 
Table 1 Absolute Import Dependence Characteristics for the Industrial Groups of the Enterprises in the Nizhny Novgorod regionfor the period from 2007 to 2009

\begin{tabular}{|c|c|c|c|c|c|c|c|}
\hline \multirow[b]{3}{*}{$\begin{array}{l}\text { Description of the } \\
\text { studied industries }\end{array}$} & \multicolumn{6}{|c|}{ The period of study } & \multirow{3}{*}{$\begin{array}{l}\text { Rate of } \\
\text { change in } \\
2009 \text { as } \\
\text { compared } \\
\text { to } 2007\end{array}$} \\
\hline & \multicolumn{2}{|c|}{2007} & \multicolumn{2}{|c|}{2008} & \multicolumn{2}{|c|}{2009} & \\
\hline & $\begin{array}{c}\text { Share of ab- } \\
\text { solute import } \\
\text { dependence } \\
\text { of enter- } \\
\text { prises, } \%\end{array}$ & $\begin{array}{c}\text { including } \\
\text { on two and } \\
\text { more PTIU } \\
\text { components }\end{array}$ & $\begin{array}{c}\text { Share of ab- } \\
\text { solute import } \\
\text { dependence of } \\
\text { enterprises, \% }\end{array}$ & $\begin{array}{l}\text { including } \\
\text { on two and } \\
\text { more PTIU } \\
\text { components }\end{array}$ & $\begin{array}{c}\text { Share of ab- } \\
\text { solute import } \\
\text { dependence } \\
\text { of enter- } \\
\text { prises, } \%\end{array}$ & $\begin{array}{l}\text { including } \\
\text { on two and } \\
\text { more PTIU } \\
\text { component }\end{array}$ & \\
\hline $\begin{array}{l}\text { The Mechanical } \\
\text { Engineering and } \\
\text { Metal-Working } \\
\text { Group }\end{array}$ & 53 & 25 & 60 & 55 & 60 & 55 & 113 \\
\hline $\begin{array}{l}\text { The Chemical and } \\
\text { Petrochemical Group }\end{array}$ & 30 & 25 & 38 & 40 & 54 & 57 & 180 \\
\hline
\end{tabular}

assessment of import dependence of branches in components of products of technical and industrial use, namely: raw stock, materials, component parts, semi-finished products and manufacturing equipment.

Calculation of values for an import dependence factor in the regional industries from 2007 to 2009 was carried out by way of methods of import dependence analysis elaborated by the author.

When calculating import dependence factor values for the regional industries from 2007 to 2009 it was revealed that there was a situation of absolute import dependence at the rate of $100 \%$ (Table 1). It means that $53 \%$ of the studied enterprises of the Manufacturing Industry had import dependence of $100 \%$ in terms of some single components for PTIU in 2007, and the enterprises have been functioning only based on import deliveries. For example, in the Chemical and Petrochemical group lacked at least one PTIU component. 25\% of them had $100 \%$ import dependence on two or more components.

In $200860 \%$ of the analyzed enterprises had $100 \%$ import dependence at least on one PTIU component. $55 \%$ of them had $100 \%$ import dependence on two or more components. For 2009 yearend the situation was similar and confirmed the import dependence tendency.

Thus, the number of absolutely import-dependent enterprises at least on one PTIU component in the Mechanical Engineering and Metal-Working Group increased by $13 \%$ within 3 years.

$30 \%$ of enterprises in the Chemical and Petrochemical Industry had 100\% import dependence in $2007.25 \%$ of them had $100 \%$ import dependence on two or more PTIU components. In 2008 $38 \%$ had $100 \%$ import dependence, $40 \%$ of them on two or more PTIU components. In $200954 \%$ of the enterprises had $100 \%$ import dependence. $57 \%$ of them required two or more import PTIU components. In other words, the number of absolutely import-dependent enterprises at least on one PTIU component in the Chemical and Petrochemical Industry increased by $80 \%$ within 3 years.

Based on the calculation of the import dependence factor values for enterprises, a branch-wise complex import dependence factor (BCIDF) was determined, which had positive import dependence dynamics for both groups within three years (Fig.1, 2).

Comparison of the BCIDF values (Table 2) gave ground for the following conclusions: import dependence for the both groups of economic activities

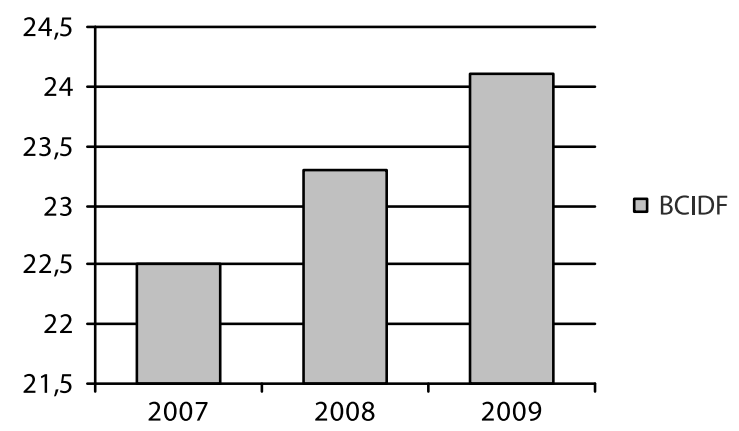

Fig. 1. Complex Import Dependence Factor for Mechanical Engineering and Metal-Working Group from 2007to 2009

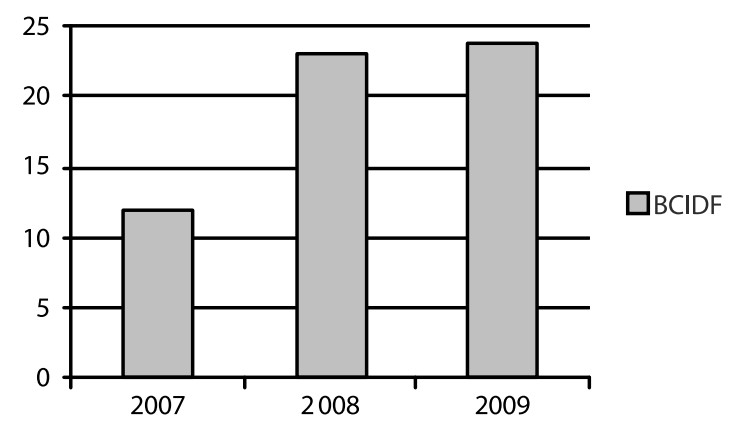

Fig. 2. Complex Import Dependence Factor for Chemical and Petrochemical Industry from 2007 to 2009 
Table 2 Comparison of Values of the Branch-wise Complex Import Dependence Factor for the Nizhny Novgorod Regional Industry for the period from 2007 to 2009

\begin{tabular}{|c|c|c|c|c|c|c|}
\hline \multirow{3}{*}{ Description } & \multicolumn{5}{|c|}{ The period of study } & \multirow{3}{*}{$\begin{array}{c}\text { Rate of change in } 2009 \\
\text { as compared to } 2007, \\
\%\end{array}$} \\
\hline & \multirow{2}{*}{2007} & \multicolumn{2}{|c|}{2008} & \multicolumn{2}{|c|}{2009} & \\
\hline & & Absolute value & $\%$ by 2007 & Absolute value & \% by 2008 & \\
\hline $\begin{array}{l}\text { BCIDF "Mechanical } \\
\text { Engineering and Metal- } \\
\text { Working Group" }\end{array}$ & 22.8 & 23,3 & 104 & 24.1 & 103 & 106 \\
\hline $\begin{array}{l}\text { BCIDF "Chemical and } \\
\text { Petrochemical Group" }\end{array}$ & 11.9 & 23.2 & 195 & 23.8 & 103 & 200 \\
\hline
\end{tabular}

Table 3 Summary Table of the Import Dependence Factor for the Nizhny Novgorod Regional Industry in respect to the PTIU for the period from 2007 to 2009

\begin{tabular}{|c|c|c|c|c|c|c|c|}
\hline \multirow{3}{*}{$\begin{array}{l}\text { Description of import } \\
\text { dependence factors }\end{array}$} & \multicolumn{6}{|c|}{ The period of study } & \multirow{3}{*}{$\begin{array}{c}\text { Average } \\
\text { absolute value } \\
\text { of a factor }\end{array}$} \\
\hline & \multirow[b]{2}{*}{2007} & \multicolumn{2}{|c|}{2008} & \multicolumn{2}{|c|}{2009} & \multirow{2}{*}{$\begin{array}{c}\text { Rate of } \\
\text { change in } \\
2009 \text { as } \\
\text { compared } \\
\text { to } 2007, \%\end{array}$} & \\
\hline & & Absolute value & \% by 2007 & Absolute value & \% by 2008 & & \\
\hline \multicolumn{8}{|c|}{ "Mechanical Engineering and Metal-Working Group" } \\
\hline IDFRM & 0 & 0 & & 0 & & 0 & 0 \\
\hline IDFMB & 20 & 20 & 100 & 17 & 85 & 85 & 19 \\
\hline IDFSFP & 13 & 14 & 108 & 14 & 100 & 108 & 14 \\
\hline IDFC & 43 & 42 & 98 & 45 & 107 & 105 & 43 \\
\hline IDFME & 30 & 50 & 167 & 45 & 90 & 150 & 42 \\
\hline \multicolumn{8}{|c|}{ "Chemical and Petrochemical Group" } \\
\hline IDFRM & 18 & 35 & 194 & 28 & 80 & 155 & 27 \\
\hline IDFMB & 14 & 21 & 150 & 15 & 71 & 107 & 17 \\
\hline IDFSFP & 0 & 14 & 0 & 8 & 57 & 0 & \\
\hline IDFC & 8 & 18 & 225 & 32 & 177 & 400 & 19 \\
\hline IDFME & 21 & 33 & 157 & 34 & 103 & 162 & 29 \\
\hline
\end{tabular}

under study has been increasing with every coming year.

Whereas at the Mechanical Engineering and Metal-Working Group the BCIDF increase was 6\% in 2009 as compared to that of 2007, the BCIDF value at the Chemical and Petrochemical Group increased by $100 \%$ within that period.

The analysis of the import dependence factors for the regional industries in respect to the PTIU components for the period from 2007 to 2009 (Table 3 ) showed steady dynamics of import dependence, namely: $400 \%$ for component parts (IDFC) (in 2009 , as compared to 2007), $162 \%$ for manufacturing equipment (IDFME) (in 2009, as compared to 2007) in the Chemical and Petrochemical Industry and $105 \%$ for component parts (IDFC) (in 2009, as compared to 2007) in the Mechanical Engineering and Metal-Working Group.

There were rather high indices of import dependence for raw materials (IDFRM), namely: $35 \%$ in 2008 and $28 \%$ in 2009 in the Chemical and Petrochemical Industry and $50 \%$ for manu- facturing equipment (IDFME) in the Mechanical Engineering and Metal-Working in 2008 and 45\% in 2009.

There was no reduction trend regarding import dependence on semi-finished products in the Mechanical Engineering (IDFSFP), it was 108\% in 2009, as compared to 2007.

Upon the whole, it may be concluded that the studied groups of economic activities in the industry have the following critical points of import dependence on PTIU (given in Table 3): component parts and manufacturing equipment at the Mechanical Engineering and Metal-Working group; raw materials, component parts and manufacturing equipment at the Chemical and Petrochemical Industry. Therefore, import substitution should be aimed first of all at overcoming the critical state of import dependence on the specified PTIU components within the studied branches.

An overall pattern of import dependence for single regional industries is added by the comparative analysis of the import and export tendencies for the 


\section{thousand USD}

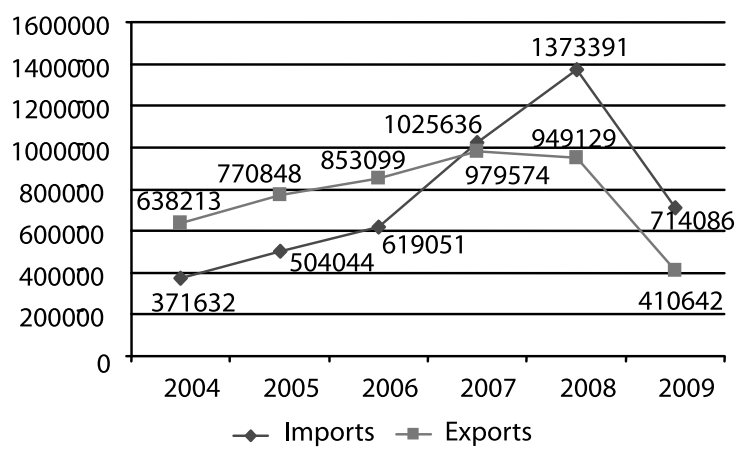

Fig. 3. Dynamics of Exports-Imports of Mechanical Engineering Products in the Nizhny Novgorod Region from 2004 to 2009

period from 2004 to 2009 performed on the basis of the Volga Customs Department record.

The import of mechanical engineering products in the Nizhny Novgorod region predominated from 2007 to 2009 over the export of the same products. (Fig. 3). In 2009 such difference was nearly twofold.

The comparative analysis of imports and exports of chemical products has revealed tendency generation for prevailing of imports over exports in 20082009 in spite of imports decrease in 2009 by $28 \%$, as compared to that in 2008 (Fig. 4).

Import dependence poses serious potential threat to the industry of the Nizhny Novgorod region in case of the following probable negative occurrences:

1. Breach of diplomatic relations with importing countries.

2. Consequences of possible economic crises and technogenic catastrophes in respective industries of states supplying our enterprises with PTIU.

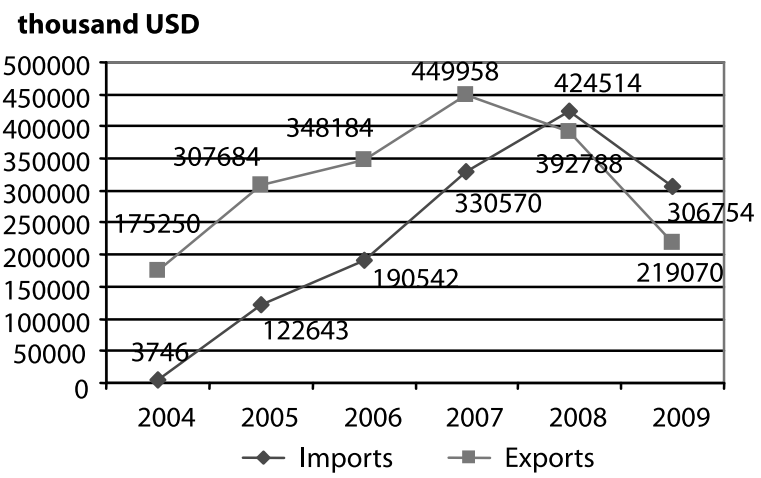

Fig. 4. Dynamics of Exports-Imports of Chemical Products in the Nizhny Novgorod Region from 2004 to 2009

We consider that the performed analysis of commodity import dependence of enterprises and groups of economic activity in the regional industry has demonstrated the necessity to elaborate and implement measures for import substitution arrangement, first of all, for critical sectors of PTIU with the purpose to improve regional economic security.

\section{References}

1. Federal Law №165-FZ “On Special Protective Antidumping and Compensation Measures in Merchandise Imports" (as revised in December 30, 2006). Retrieved from: http:/www. lawstore.ru/2504/35931.html (date of retrieval: 10.10.2010)

\section{UDC 339.9.01}

Key words: commodity import dependence, critical import dependence, import dependence factor, regional economic security hazard 